\title{
But They Purloined My Coat: Walking Through the Actor's Process of Entering into the Role of Tom Collins in Jonathan Larson's Rent
}

Cameron Amir Khoshgam

West Virginia University, cak0046@mix.wvu.edu

Follow this and additional works at: https://researchrepository.wvu.edu/etd

Part of the Acting Commons, and the Performance Studies Commons

\section{Recommended Citation}

Khoshgam, Cameron Amir, "But They Purloined My Coat: Walking Through the Actor's Process of Entering into the Role of Tom Collins in Jonathan Larson's Rent" (2021). Graduate Theses, Dissertations, and Problem Reports. 8237.

https://researchrepository.wvu.edu/etd/8237

This Thesis is protected by copyright and/or related rights. It has been brought to you by the The Research Repository @ WVU with permission from the rights-holder(s). You are free to use this Thesis in any way that is permitted by the copyright and related rights legislation that applies to your use. For other uses you must obtain permission from the rights-holder(s) directly, unless additional rights are indicated by a Creative Commons license in the record and/ or on the work itself. This Thesis has been accepted for inclusion in WVU Graduate Theses, Dissertations, and Problem Reports collection by an authorized administrator of The Research Repository @ WVU. For more information, please contact researchrepository@mail.wvu.edu. 
But They Purloined My Coat: Walking Through the Actor's Process of Entering into the Role of Tom Collins in Jonathan Larson's Rent

Cameron Amir Khoshgam 


\title{
But They Purloined My Coat: \\ Walking Through the Actor's Process of Entering into the Role of Tom Collins in Jonathan Larson's Rent
}

\author{
Cameron Khoshgam
}

Thesis submitted

to the School of Theatre \& Dance

at West Virginia University
In partial fulfillment of the requirements for the degree of
Master of Fine Arts in
Acting

Jay Malarcher, Ph.D., Chair

Jessica Morgan, M.F.A.

General McArthur Hambrick, M.F.A.

\author{
School of Theatre \& Dance \\ Morgantown, West Virginia \\ 2021
}

Keywords: Theatre, Acting, Rent, Jonathan Larson, Community, Imaginary Body, Michael Chekhov, Gay, AIDS, COVID-19

Copyright 2021 Cameron Khoshgam 


\begin{abstract}
But They Purloined My Coat: Walking Through the Actor's Process of Entering into the Role of Tom Collins in Jonathan Larson's Rent
\end{abstract}

\title{
Cameron Khoshgam
}

To explore an actor's process is to explore the foundation of all acting methods. The purpose of this document is to do just that. From character creation to final performance of the role of Tom Collins in West Virginia University's spring 2021 production of Jonathan Larson's Rent, this document will share a detailed look at research into the historical framework of the musical, the playwright, and character inspiration in the pursuit of crafting a well-rounded understanding of the show. Additionally, it will provide an account of textual analysis, an in-depth look at the rehearsal process, and various acting techniques used to build the inner life of the character, specifically focusing on Michael Chekhov's technique of the Imaginary Body and Kristin Linklater's Dropping In exercise. It will also recount the pitfalls that impeded these steps in my acting process as well as reflect on the outcome of the production as a whole. 


\section{Table of Contents}



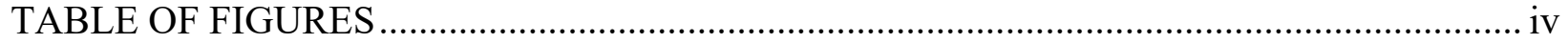

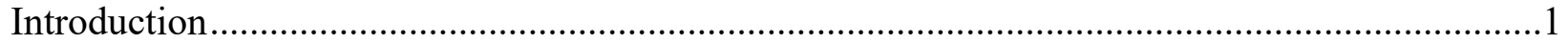

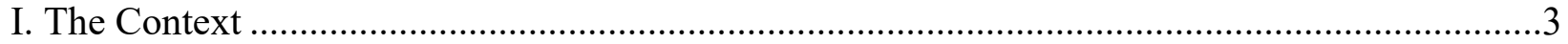



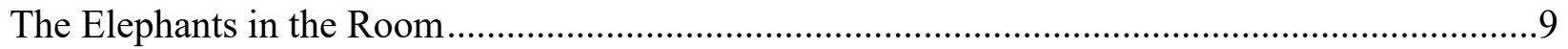

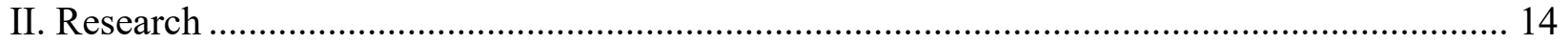

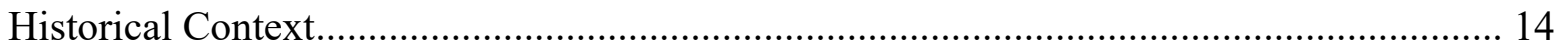

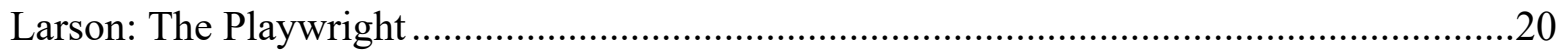

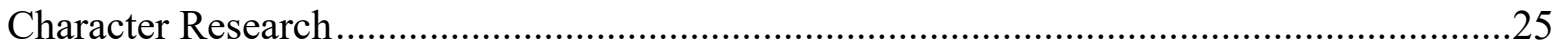

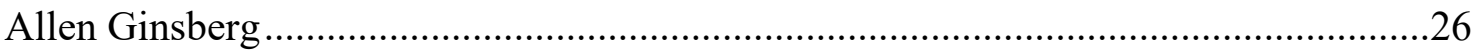

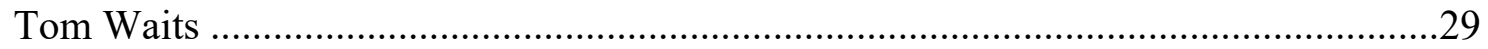

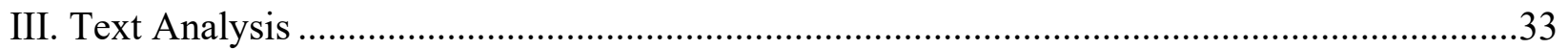

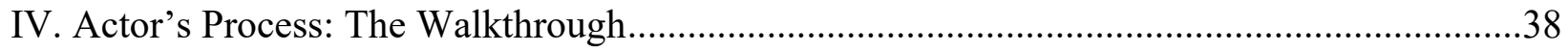

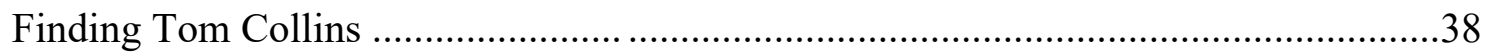

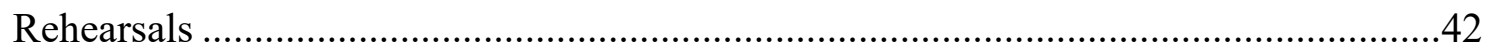

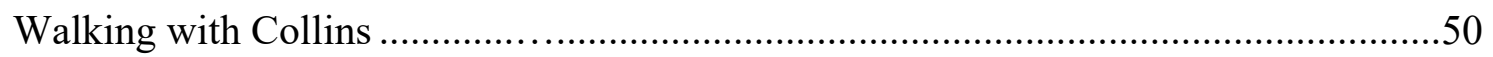

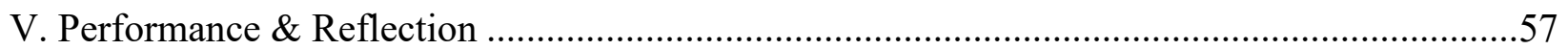

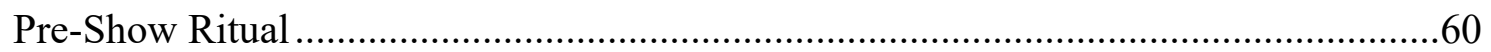

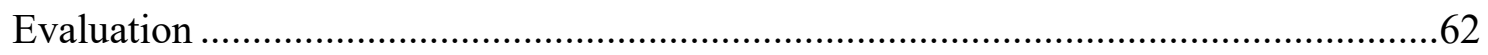




\section{Table of Figures}

Fig. 1 Larson, Jonathan. Rent. 1996. Screenshot. Musical Theatre International .......................33

Fig. 2 Burroughs, William. Allen Ginsberg on the rooftop of his Lower East Side apartment. 1953. Photograph. New York Times. https://www.nytimes.com/2006/11/19/books/Kirn.t.html. Accessed 19 April 2021 


\section{Introduction}

I have never been one for self-reflecting, if you asked any teacher that has required me to keep a journal they would say it reads more as a textbook than a collection of my thoughts. I tend to focus more on research and ideas rather than how things make me feel but this process has unearthed a sense of emotional attentiveness in me. Discovering the character of Tom Collins in the musical Rent by Jonathan Larson has sent me down a path of self-discovery as an artist and as a human being.

The process of creating the character in tandem with working with my fellow ensemble to put up this show in less than a month was hectic to say the least. Having to deal with the COVID-19 pandemic and the loss of a director in the span of the spring 2021 semester at West Virginia University was no easy task. This thesis will serve as an account deconstructing my personal role in creating this collaborative story. I will delve into the research side of creating a character and how the entirety of my educational experience before the performance influenced and enhanced my work.

Despite the challenges we faced as an ensemble we had a successful run. Most importantly, we were able to connect to each other and share an experience that I will not soon forget.

I had initially gone into auditions for the School of Theatre \& Dance's season thinking I would be forced into another show entirely, but I was given the choice to pursue my final role at the university in Jonathan Larson's Rent in tandem with filming a production of King Lear by William Shakespeare. I had made it clear that I would have preferred to perform in the musical, and subsequently was shoehorned into both productions. 
Exploring the character of Tom Collins was an experience I would not trade for anything. In finding him, I was able to unlock aspects of my personality that I had not put much stock into but that now have changed my perspective on life and art completely. Performing this rockopera $^{1}$ during the COVID-19 pandemic was both a challenge and a blessing because it gave context to a show that had its feet rooted in two different centuries, connected by a thread of loss and disease. I have come to the realization that the community we build with our art is vastly more important than the performances we give, and I think the story that the company behind Rent was able to put together exemplifies just that.

\footnotetext{
${ }^{1}$ Rock-opera: Referring to a collection of rock genre specific music that progresses, following a plot. Usually, rockoperas are not performed and are released as concept albums, but that is not the case with Rent. Made for the stage, this piece more closely falls into a category of sung-through shows made for the stage.
} 


\section{The Context}

\section{Plot Summary}

Before exploring the character and the process required to build Tom Collins, it is important to first take stock of the world built around the character. I have included a plot summary that I will be drawing from throughout this document. Rent is almost completely sung through, with interspersing dialogue to fill in off stage events. The entire production is underscored by the orchestra, dictating the pace and consequently the mood of each scene. Rent takes place in New York, from Christmas Eve 1991 to Christmas Eve 1992.

\section{CHRISTMAS EVE'91}

The musical begins on December 24, 1991, in an industrial loft on the corner of $11^{\text {th }}$ Street and Avenue B. Mark Cohen, a documentary filmmaker and narrator of the plot, begins the story through direct address of the audience. He is working on a documentary throughout the musical and Larson uses this framing device to give Mark narrative soliloquies as he speaks to his camera. The musical starts with Mark filming his roommate, Roger Davis, who is failing at writing what he deems will be, "one great song" (Larson 3).

Tom Collins (referred to as Collins) returns to town, and while calling up to receive the keys to Mark and Roger's apartment he is attacked by three men who steal his coat (“Tune Up A" \& “Tune Up B"). ${ }^{2}$ The two roommates are then given a surprise visit from their friendturned-landlord, Benjamin Coffins III, whom they refer to as, "Benny." He calls the two artists demanding their rent ("Rent"). Before Benny arrives at the apartment, Mark's old roommate,

\footnotetext{
2 ("Tune up A" \& “Tune Up B"): Referring to the songs in which the plot progresses though. Rent is primarily sung through, meaning that a significant majority of the plot is played out through musical numbers. Throughout the chapter, I will denote the significant musical numbers tied to the plot this way.
} 
Collins is patched up by Angel Dumott Schunard, a drag-queen drummer; she introduces herself as a "comfortable home for the Acquired Immune Deficiency Syndrome", Collins, then tells her he has contracted AIDS as well and they run off together ("You Okay, Honey").

The scene then shifts to Mark explaining to Roger that his ex-girlfriend, Maureen Johnson has asked him to help fix the sound system at her protest later that evening. Mark reveals to the audience that Roger is in mourning for his girlfriend April, who committed suicide after learning she had AIDS while Roger sings of his desire to write one lasting song before his own death ("One Song Glory”). Mimi Marquez, neighbor, night club dancer, and junkie, enters Roger's apartment and flirts with him, asking him to light a candle she keeps blowing out, all while looking for her lost stash ("Light My Candle").

Mark reenters the apartment with Collins who brings gifts of coffee, food, and firewood. He introduces them to Angel who retells the story of how she paid for all the gifts Collins had recently brought in by killing an Akita named Evita ("Today for You A" \& "Today for You B"). Benny confronts the group, giving them the choice to either pay rent or stop Maureen's performance protesting his removal of the homeless from the Eleventh Street. Roger and Mark blow off Benny, and Collins and Angels invite the two to the Life Café after Maureen's show and to a Life Support, an AIDS support group, meeting beforehand ("You'll See").

Mark makes a detour to fix Maureen's equipment and there he meets Joanne Jefferson, Maureen's current girlfriend. Joanne admits to Mark that Maureen has been cheating on her as Mark fixes the technical issues at the performance space ("Tango Maureen").

Mimi performs a song and dance routine in the nightclub about her desire to go out and have a good time before her life ends ("Out Tonight"). Mimi’s song transitions into her barging 
into Roger's apartment to take him out, but he scolds her brazenness and runs her off ("Another Day").

Mark gets accosted on the street by a homeless woman while trying to protect her from harassment from the police and Collins and Angel lament about living in New York ("Santa Fe”). Mark then goes off to pull Roger out of the apartment, leaving Collins and Angel to express their love to each other, strolling the streets of the Lower East Side ("I'll Cover You").

Mark convinces Roger to invite Mimi to the Life Café after the two see her buying drugs from her dealer and the five of them (“On the Street”), ${ }^{3}$ Angel, Collins, Mark, Mimi, and Roger attend Maureen's protest performance (“Over the Moon”). That night at the Life Café, everyone meets up to find Benny entertaining his investors at the same restaurant. He tries to explain to the group that he is only trying to clean up the Lower East Side, telling them they are acting out of place, that, "Bohemia's dead" (Laron 61). Mark then leads the patrons of the restaurant in a mock funeral for Bohemia to drive out Benny and his investors.

During Mark’s mock funeral, Roger and Mimi gather outside, expressing feelings for each other. Mimi finds out that Roger has AIDS and reveals to him that she has contracted AIDS as well. Realizing that he shares the same baggage as Mimi, Roger gives into loving her and the two re-enter the cafe to celebrate their newfound relationship. Inside, Joanne confronts Maureen about walking all over her and kicks her out of her place, she also announces to the restaurant that Maureen's performance sparked a riot on the Lower East Side, and they all go to join the chaos while Mark captures it on film. The riot ends the first act of the musical with a nod,

\footnotetext{
${ }^{3}$ This song was cut from our performance, but it provides an explanation for Mimi to be at the Life Café during "La Vie Boheme".
} 
intentional or not, to the end of Act 1 in the musical Les Misérables "(La Vie Boheme/I Should Tell You").

\section{NEW YEAR'S EVE}

The next act begins with an ode to love and life with the entire cast singing "Seasons of Love." Waiting for Collins and Angel, Mark, Roger, Mimi, Joanne, and Maureen celebrate the New Year. Mimi confesses that she is going to give up her drug habit and go back to school while they try to break into Mark and Roger's apartment (They were evicted by Benny after refusing to help him with the protest). Angel and Collins arrive, and Angel breaks bolts to the door with a blow torch (“Happy New Year B”) as Alexi Darling from Buzzline, calls Mark, wanting his footage on the riots that took place after Maureen's performance ("Voice Mail \#4").

As they count down to the new year, Benny shows up to convince Mark to film him giving a fake apology for the "unfortunate circumstances of the last seven days" (Larson 82). Roger sees as an obvious "photo opportunity" after just hearing that Buzzline, a sleazy tabloid news show, wants Mark's footage of the riot, so Benny reveals that Mimi had dropped by his place to seduce him into giving them back their apartment. Angel then tries to defuse the situation by giving her condolences for Benny's wife's dead Akita (the one she killed in Act 1) while pushing Roger and Mimi closer together (“Happy New Year B”).

\section{VALENTINE'S DAY}

Mark catches the audience up on what has been happening the past month and a half as we reach Valentine's Day: Joanne and Maureen are working on Maureen's new performance piece, Roger and Mimi have been spending almost every moment with each other, and Collins and Angel have vanished from the public view. 
As Maureen and Joanne rehearse, Joanne is taking advantage of Maureen's promise to obey her every wish, as atonement for her infidelity. Maureen eventually blows up at Joanne and she admits that she is hurt by the fact that Maureen is continuing to flirt with other people, specifically a woman in leather. The couple then fights about how they both feel disrespected, and they walk out on each other, ending their relationship ("Take Me or Leave Me").

\section{SPRING}

Mimi's relationship with Roger begins to suffer when he confronts her for coming home late and accuses her of sleeping with Benny. Mimi breaks down and uncovers that she has fallen off the wagon and has been struggling with a way of telling Roger, without the possibility of him leaving her. The two then express that they couldn't live without the other ("Without You").

\section{SUMMER/FALL}

Summer passes into fall. All the ensemble's relationships are struggling; it is revealed that Angel is getting progressively sicker, and as every other relationship ends in their own way, Angel dies as her condition overtakes her ("Take Me").

Collins and others give speeches at Angel's funeral ("I'll Cover You- Reprise") After the funeral, Mark has a crisis of morality, and after seeing his friends back together and witnessing the pain of losing Angel, he regrets his decision to accept Alexi's offer and work at Buzzline ("Halloween"). Roger and Mimi argue about how she is now sleeping with Benny and about him moving to Santa Fe. Maureen, Benny, and Joanne all join in the argument. Collins breaks up the argument, Maureen and Joanne get back together, and Mark is left alone with Roger.

Mark confronts him about running just as Mimi rushes back in. She runs Roger off after learning that he is leaving because of her, and she confesses to Benny and Mark that she needs to 
go to rehab ("Goodbye Love"). Collins is then kicked out of the church for not having the money to pay for the funeral and Benny comes to the rescue, agreeing to pay for Mimi's rehab and Angel's funeral (even after Collins admits that Angel killed his wife's dog). The fall ends with Mark coming to his senses and quitting Buzzline to work on his own documentary film ("What You Own").

\section{CHRISTMAS EVE' '92}

On the eve of December 24, 1992, Roger and Mark's apartment has been transformed into a makeshift theatre as he is setting up for a viewing party of his new film. Roger has sold his car and moved back to New York to be with his friends and to find Mimi, he is still writing his one great song. The power shuts off right as Collins shows up with a stack of twenty dollar bills he has stolen from the ATM at the Food Emporium. Maureen and Joanne scream for help and bring a very sick and very weak Mimi into the apartment ("Finale A"). Roger sees that Mimi is dying of her illness and sings his completed song to her, "Your Eyes", as she appears to be dying. Mimi wakes up and retells to the group that she had seen Angel and that she had told her to turn around and "listen to that boy's song" (Larson 117). The musical ends with the power coming back on and the group of friends watching Mark's footage from the last year ("Finale B'). 


\section{The Elephants in the Room}

Coming into this production, we were faced with many factors that impeded our ability to come at this process with a full spectrum of creativity and collaboration. The first factor we had to deal with as a company was putting together a show during a global pandemic. We all had to audition via self-tape, and our call backs were via Zoom. Not only were there technological barriers between our audition and the director's casting decisions that has little to do with our acting talent, but there was the fear of the show never going up. The year before, the School of Theatre \& Dance at West Virginia University had to cut the spring 2020 main stage musical completely out the season due to the COVID-19 pandemic. This was a show that had been funded, designed, built, and rehearsed—almost completely ready to perform in front of an audience. This unfortunate event was similar to what happened to many productions across the world. Broadway shut its doors and they still have not opened as of July 2021 and many community and regional theatres across the world started taking donations and putting together online fundraisers to help keep themselves afloat, so the production was in jeopardy before it started. The School knew very little about the decisions that the University would make to keep its students safe, so even before auditioning for Rent there was confusion and a lack of faith in the process.

On top of the scare of COVID, at the start of the spring 2021 semester our director left the university. Professor Jeremiah Downes, the original director of the production, had already cast the show and met with the designers, explaining his vision. The cast was left in the dark for months while the administration tried to find a replacement for Downes. They ultimately had to figure out what to do with a show that already had a full cast of students ready to perform, learn from, and create while dealing with the possibility of having to cancel the show entirely due to 
unforeseen circumstances relating to the pandemic. During the spring 2021 semester, either because of COVID restrictions or the inability for the School of Theater \& Dance to find a viable director, our rehearsals, which were supposed to begin in early February of 2021, were pushed back week after week until our new director, Professor Leland Blair, Associate Director for the School of Theatre \& Dance, was announced and we were told we were to be meeting at the end of March. Obviously, there was a lot of confusion and unanswered questions throughout the process because, by the time we had started rehearsal our new director, Professor Blair was working with a cast he did not choose, on a show he professed to know little about, and on a timeline that had been shortened by about two months. On top of all of the confusion, we had to work under strict COVID guidelines that changed the scope of the show and how rehearsals had to be conducted. Luckily, we were able to meet in person the entire rehearsal process, but the stress put upon us was palpable.

Personally, a large hurdle I had to jump over was working in a separate production during the time I needed to be learning Rent. I was cast as Cornwall in the first main stage production of the spring 2021 semester, King Lear by William Shakespeare. The University had paired with West Virginia Public Broadcasting to produce a feature-length film version of Shakespeare's classic. As with many feature films — meaning any film that is around and hour and fifteen minutes to two hours long__ the process of filming King Lear was a large task. I was called to almost every rehearsal, expected to do extensive text work, and had to work with the director who was not all too familiar with directing a large-scale film project. Our director for the play, Professor Jerry McGonigle, Director of Graduate Studies, had a lot on his plate directing and producing this project, so many of my questions on how I needed to split my time between shows were left unanswered. Even though performing in Rent was the performance aspect for 
completion of my thesis, King Lear was such a large, collaborative project that its scheduling took precedent. A lot of nights, they would call a good portion of the cast that was not needed for filming to stand by in case they were able to move on to shots they may have been able to squeeze in. Many nights, I waited around doing nothing but sitting in the dressing room at the Loulie, William and Valerie Canady Creative Arts Center (CCAC), running lines for a scene we would not get to shoot. Ultimately, that meant I was losing precious time to work on Rent. Luckily, the production schedule of Rent was pushed so far to the end of the semester that filming King Lear never impeded directly with attending rehearsals. In the end, I was lucky to have had time to perform in both pieces and the only real setbacks were the added stress the back-to-back schedules gave me and the lack of time I had to research the role of Tom Collins.

The final factor that honestly caused most upset about our performance was the lack of diversity the School of Theatre \& Dance was able to bring to our show. The background against which the action is set, the AIDS outbreak in the late-1980s, early-1990s and the gentrification of the East Village, not only informed the creation of the musical, but is fundamental to understanding the privilege and lack of awareness we had when performing this story. The characters that this musical is built around are complex and harrowing at times, but they represent an unseen marginalized community built around art and rebellion and clawing your way through a world that is against you at every turn. The history of Rent is steeped in one white man's ambition to make the world a more visible place for the queer community, people struggling to live with AIDS, and struggling artists. In 1996, the number of people living with this disease was upwards of twenty million (History of HIV) and by time the musical was over twenty years old (2018) forty-two percent of Americans who had been diagnosed with HIV were Black (HIV and African American people). 
Jonathan Larson died before he could see his play have any lasting effect on the world, and unfortunately in the mainstream, while it did bring awareness the musical itself fetishizes impoverished communities by drawing in mainly rich, white audiences rejoicing in a story about community and struggle they never have to experience. With the best intentions we usually do not look towards the people we cast to the wayside. Diversity and inclusion are important part of every human interaction, so when all but three of our cast represents a community of wealth and power in their whiteness that is an issue.

It did not hit me until we were running through one of our dress rehearsals. It started to snow, and of course we were prepared with space heaters on the stage for cast and crew to huddle under in order to stay warm for the length of the rehearsal, but the homeless community living in the Ruby Hazel Park were relying on blankets and shared warmth. They would come down into the audience to watch us perform and to rest in the seats, and I could see the disgusted and concerned looks on my fellow company members faces towards the very human being we were trying to bring awareness to. The image of us dressed as homeless, impoverished bohemians, telling this story one minute then, huddling under fancy heat lamps the next, all while the people we were representing went cold and uncared for was immensely distressing to me. It felt like we were missing the point. It made me wonder why we were performing this show in the first place.

Around the time our show was in dress rehearsals, students in the School of Theater \& Dance started posting on social media about how "whitewashed" our show was, calling it "went." The online criticism was met by the faculty trying to "shut it down" while supporting the company's dedication and hard work, telling us that no matter what was said online they were proud of our performances and that they stood by us no matter what our peers were saying. That 
was the wrong response. This show was performed in an educational setting and our teachers, our mentors, our guides did not take this opportunity to talk about why our fellow students were saying that this show was whitewashed or inequitable. The conversation was pushed to the side so nobody felt uncomfortable, but unfortunately many people did feel uncomfortable. Obviously, our performance had an adverse effect on a community to such a degree that they felt it was important to speak out. I always say, "Art is political.” It is meant to change our hearts and our minds, and we had a real chance to do that by simply opening up conversation. Yet, we valued comfort over the truth.

Blanket Person's response to Mark filming her being abused by police officers in the song "On the Street" speaks volumes to this point: "My life's not for you to make a name for yourself on" (Larson 41). In an artistic medium which lives and dies on prying eyes, it would be a mistake to overlook such a sentiment.

I was in a role made famous by a Black actor, Jessie L. James. Canonically, Collins has been performed almost exclusively by other actors of color, at least in mainstream productions of the show. The only instance of a white actor playing Tom Collins was in 1994 during the New York Theatre Workshop production of Rent when glam rocker Pat Briggs originated the role. Despite the demographics of the university being almost completely white and the school's initiative to open up the audition process to more than majors within the School of Theatre \& Dance to diversify the casting pool, it didn't sit well with me that I performed the show and never formally spoke up about the very real issue of equity and inclusion in our performance. Though I had my own image of this Tom Waits-esque Tom Collins that Jonathan Larson described, I never really thought it was a possibility for me to play the role because of the rich history of Black men performing him. At this point, I do not think I would accept the role again or should have 
accepted the role in the first place; that is less about what Larson wrote initially and more of what the role now represents. Jesse L James changed the landscape of who should perform Tom Collins, and as artists we should not only respect, but celebrate, what the character now represents.

\section{Research}

\section{Historical Context}

The process of creating any art is rooted in the world around the artist. It is important to the actor to cross the line and examine the reality in the world they must create their character. Jonathan Larson crafted his world using the backdrop of 1990s New York, Lower East Side, a place he knew very well. New York was the breeding ground of Larson's artistic creativity. As a gay man, he lived through the dangers of being who he was and loving who he loved. As an artist, he lived through financial instability and criticism not only from his peers, but also from the world he inhabited.

Before diving into Larson's biography, I had to examine the world he created in. In every actor's journey the historical backdrop of the story gleans insight and understanding to two questions unanswerable just buy examining the text. So, in my acting process it is paramount to my success to dive into the reality behind the text that fuels the playwright's artistic expression.

In 1996, Rent became a national phenomenon. The musical was Jonathan Larson's last imprint on the world, and an artist's death rarely decreases the value of their work. Larson, heavily influenced by the '90s New York artistic underbelly and 1890s Italian Opera, $L a$ Bohème, made his mark on musical theatre history. Paralleling AIDS with tuberculosis, 
nineteenth-century Italian bohemians with struggling twentieth-century artists hit a cord with audiences and twenty-five years later, the world that Rent depicts is scarily familiar.

At the time, Rent was far from a period piece, but from 1996 to 2021 the world has seen an exponential growth in technological development, social justice movements, and overall understanding. The movement of people and ideas is happening faster and faster, and to keep up the landscape of our reality has shifted just as fast. Tom Collins walking into a telephone booth at the top of the show is lost on most of the younger college audiences that helped populate our performances, and that realization meant that it was just as important to dive into the historical aspect of Rent as I would with a show like Pride and Prejudice. As a gay man playing a gay character written by a famously gay playwright, I thought it paramount that I study the history of gay men's relationship with AIDS, specifically in the theatrical concept. Two works of art flooded to the forefront of my mind when I thought about how I wanted to go about researching other works steeped in this topic: Angels in America: A Gay Fantasia on National Themes by Tony Kushner and Falsettos by James Lapine and William Finn.

Lapine and Finn's Falsettos focuses on family and how queerness in the 1980s/90s affected the traditional nuclear dynamic. Marvin, the protagonist, leaves his wife for his lover whom we find later is dying of AIDS. The sung-through musical, much like Rent, helped depict and normalize parts of the gay narrative in the mainstream. We then have Tony Kushner's Angels in America: the play deals with gay heartbreak, coming out, and identity crises all circling around the burgeoning AIDS epidemic in the 1980s. These stories are a history of emotional experiences, and a depiction of struggles for gay men in a time when it was quite literally a death sentence to be gay in America. Why these two pieces came to mind when thinking about the character of Tom Collins was best expressed in an article I came across while researching 
gayness in theatre. Jesse Green expresses in A Brief History of Gay Theater, in Three Acts the complicated identity and history of the gay man living in America:

The deeper reason this material holds up despite being so tied to its times is that gayness, even now, does not operate as other minority identities do. Gay people are not usually raised in gay families, the way Jews are raised in Jewish ones, and blacks in black ones; gays have to invent their identity from scratch in every generation. And even if there were a healthy tradition of mentorship by gay elders, the population of gay elders-the ones who would now be in their ' 60 s and '70s—-was decimated by AIDS. So whatever advances have been made in supportive parenting, the process by which a gay man finds himself and his people is much the same as it ever was: Ontogeny recapitulates phylogeny. Or to put it more gaily, you are what we were. (Green 5)

This is the culture. A culture of fear and hiding. We learn through experience and exploration, and in a time where that kind of experience and exploration can get you killed, we turn to art and stories. We turn to teachers who touch us with their words and their music. Personally, growing up in Texas, I turned to art and music to "parent" me in the ways of a culture I was scared to be a part of, and to throw in the fear of a disease that only years before was named after you increased the urgency hide parts of yourself you didn't fully understand. ${ }^{4}$ To see stories like these in the mainstream must have been a lifeline. New York wasn't shy of queer representation, Harvey Firestein's Torch Song Trilogy had its roots at La Mama

\footnotetext{
${ }^{4}$ The syndrome was initially called gay-related immune deficiency (or GRID). "In the period June 1, 1981-April 12, 1982, CDC received reports of nineteen cases of biopsy-confirmed Kaposi's sarcoma (KS) and/or Pneumocystis carinii pneumonia (PCP) among previously healthy homosexual male residents of Los Angeles and Orange counties, California. Following an unconfirmed report of possible associations among cases in southern California, interviews were conducted with all eight of the patients still living and with the close friends of seven of the other eleven patients who had died" (CDC).
} 
Experimental Theater Club, a gay-friendly theatre in downtown Manhattan, [but] many other popular gay shows were not nurtured or brought to light outside of the few of these spaces. That is why when Angels in America first emerged at two nongay theatres it made such a lasting, inspirational effect (Piepenburg 1). That effect was the exploding growth of the gay narrative in art.

The way the world sees gay people and the way gay people see themselves have changed so much, and of late so fast, that plays from even just a few years ago can seem like Ken Burns documentaries. In one sense, then, the classic gay plays are educational: reminding a complacent generation of the struggles and tragedies (and fabulousness) that underlie the glossy image of rapid progress. The normalization of gayness that has in most ways been a boon has also shrunk the historical eye. (Green 2)

Green's take on the change is mainstream gay culture stems from the room that Kushner, Firestein, Larson, and Finn gave it grow. Like transferring a small fish into a larger tank, that room allows the body of queer art to grow and diversify. Conversely, that makes the job of an actor more difficult. Yes, there is a lot more representation, but moving farther away from the struggle and fear that encapsulated the 1980 s and '90s creates a disconnect that can only be remedied through sifting through the works of the artists who changed the landscape to begin with.

Working on Rent, it was pertinent for me to explore bridging that disconnect. It was important to me to perform this show with truth and accuracy, but to also tell a story that was relevant and relatable. To push myself and to understand that part of the storytelling, I had to answer the simple question, "Why do we need to perform this show?" There is a need to reexamine this history. So much of the narrative about queer culture has been centered around 
entertainment for white, straight audiences. Newer generations of artists must work against the stereotypes presented to us when we were younger and finding that voice for ourselves is a daunting task. We see straight men playing our roles in the name of shining a light on gay culture, but the notion that we still need that steppingstone to make connections is outdated and driven more by money and fear of retribution rather than a want for change. It is a shame. Jesse Green touched on the topic, on how pandering to nongay audiences has shoved the canon of gay history into the history of everyone's shame. Going as far as to say it has become part of the shame of all writers since Adam and Eve (Green 6). There is still a very real shame to be who we are, as diverse as we are. It is a tiring thought to pander to straight audiences to stay relevant, and even though we see representation rising in popular media there are still pitfalls that remind us that queerness is less than straight "normalcy."

It's A Sin, an HBO Max series about LGBT 1980s London had become a fairly recent success around the time we were rehearsing Rent. It also showcased the AIDS crisis within the LGBTQ community, entering modern, popular culture. There is a want for this type of narrative. There is an inspirational quality to these pieces of art that not only root the LGBTQ+ community to our relatively recent struggles but also give us dynamic and interesting characters to live up to, or to simply show us we can fail like everyone else. There was a time when to perform a "gay play" was to shout at audiences that the queer community must be seen and there was validity to that. Now, they know we are here, so our focus needs to shift on a growing community. To keep moving forward, it is important that we showcase our inherent, intersectionality, and stories like Larson's help to showcase just that. Queer stories by queer artists were the need that we can fulfil, and my job was to perform my part with as much of myself in the role as I could muster. 
Honestly, the time I spent researching the Lower East Side of New York in the 1990s was condensed to the three-week process it took us to rehearse the show. I still think that there was a disconnect between myself and the world that Larson built, and I was nervous scrambling to find some semblance of connection between the drastically different realities in which Collins and I live. An actor's understanding of the world around them is paramount to living truthfully in circumstances, and I felt cut off at the knees in that regard. I weighted what research I was able to gather heavily to understandings I already had of the queer community in the early $1990 \mathrm{~s}$. In some respects, I am not far removed from the time, yet I know that there was a clear and present danger to gay men living with AIDS that I still do not have a grasp on. I clung to what I knew: Tom Collins is an educator, a man who finds joy in teaching others right from wrong. He is a man who finds love in everyone around him, and values keeping his community together. Those values are timeless and finding that same connection with my company really grounded me in the world we built together, whether it was rooted in historical accuracy or not. 


\section{Larson: The Playwright}

What is the playwright's hold on the work they release into the world? How much of themselves can they really expect to live on in the worlds they build if that world is expected to trade hands and be performed countless times over countless lifetimes? In a way, the playwright is just the idea man: unable to fully experience the successes and pitfalls of a living and breathing performance every time it takes stage or takes form. Composer and playwright Jonathan Larson died in 1996 at the age of thirty-five before he could witness the success of what he created, and in a way, that fueled the fire of the production's success. The morbid nature of art rising in value after the artist's death latched onto Rent without any hesitation, even Anthony Rapp (who originated the role of Mark) stated in his memoir, Without You: A Memoir of Love, Loss, and the Musical Rent, “Jonathan's death made bizarre sense; he'd not been well, he'd gotten this show out of him, which was the most important thing he'd ever done, the biggest expression of himself he could ever put out into the world, and when he was done, he'd died" (Rapp 121).

Larson's work is a love letter to the bohemian New York where he longed to make his mark. He and dramaturg Lynn Thomson crafted a Bohemia based off the Italian opera set more than 150 years in the past: La Bohème composed by Giacomo Puccini, based further on the French Scènes de la vie de bohème by Henri Murger. Through the rabbit-hole of Bohemian iterations of the story, the core community rings through. Larson focused on the relationships of the struggling artists, trying to make a difference on the world that they were stuck in, "It is not how many years you live, but how filling the time you spend here is" (qtd. in Snyderman 1).

When Jonathan Larson died of an aortic aneurysm, he solidified that community not just on the page, but with the artists he brought together with his work. The cast sung through the 
score the night after Larson's death. It was a simple sing through, but Anthony Rapp remembers the electricity of the performance:

We were doing more than a simple sing-through. Sure, we weren't moving around, and there were no lights or costumes or sets, but the undeniable electricity of a full performance positively sizzled through the air. We all felt it onstage, too, playing off each other, warming up as we went, letting loose, singing our hearts out. By the time we got to 'La Vie Boheme,' it was clear that the time for sitting down was over, and as I began my opening verse, I climbed right up onto the table, just as I did in the show, and sang out to the crowd Jonathan's joyful valentine to all things bohemian. (Rapp 129-130) Larson's Bohemia was meant to be lively and full of energy, like it was a choice to suffer in the shadow of corporate society. Jonathan Larson was born February 4, 1960, in White Plains, New York, and from a young age he was exposed to music and the performing arts, eventually going to Adelphi University in Garden City, New York where he studied acting and picked up composition. After receiving his degree four years later and then his Actor's Equity Association card the following summer working as a pianist in Michigan, Larson lived in near poverty, but he was happy. ${ }^{5}$

His New York was seen through the eyes of artists who chose to abandon their lifeline to the world outside of their art. The musical is populated with interrupting voice messages reminding them that the world in which they live was a challenge they chose. Painting that picture, we can get a glimpse at the start of Larson's career, working his way up from a server at the Moondance Diner, living in a loft alongside multiple roommates, with no heat in Lower

\footnotetext{
${ }^{5}$ Actor's Equity Association (est. 1913) is the labor union representing American actors and stage managers in the theatre.
} 
Manhattan. He was determined to be an artist, even if it meant working his way up from the bottom.

Larson's New York career began with a futuristic rock musical called Superbia in 1989 that mirrored the style and themes of George Orwell's 1984. Larson's original intent for the musical was to be a direct adaptation of Orwell's novel, but Orwell's estate did not grant him the permission to use it. Superbia was never fully produced, and the situation served as one of Larson's inspirations for the musical he described as a "rock monologue," tick, tick... BOOM! which dealt with Larson's disappointment with the response that he received from Superbia and his personal shortcomings as an artist and aging gay man in New York.

Larson was determined and artistic, working his way through menial jobs while still writing and composing in his spare time. Larson felt like his real calling was to be an artist, he drew inspiration from artists that embodied everything he wanted to be, flamboyant, passionate, off the wall. He "could notate his own music expertly, but he never considered himself a musician. 'I am a songwriter,' he would say proudly, the term of choice for the likes of [Cole] Porter, [Irving] Berlin and [Jule] Styne" (Tommasini). When he died, tapes of Jonathan Larson were found in his apartment of him wailing and "banging on the keys covering artists like Billy Joel and Elton John, seemingly trying to ingest them into his musical vocabulary" (Tepper). He was shaped by musical icons who embraced fame and camp and artistry. When asked who his motivations were, he stated that he loved, "Pete Townshend [of The Who] growing up, and loved the old Police and Prince ... I love Kurt Cobain [of Nirvana] and Liz Phair. Beatles. And in the theatre-Leonard Bernstein, [Stephen] Sondheim" (Istel). He wrote what he knew, and what he wrote was rich with autobiographical text, so much so that researching biographies and stories of the composer felt like getting to know his characters. Julie Larson McCollum, Jonathan Larson's 
sister, recounted that, "He was thrilled. I remember he called us up all the time when they were casting Rent. It was important to him that the cast be young, passionate and sexy" (qtd. in Snyderman 2). To me, it was important to figure out why he wanted that cast to be young, passionate, and sexy. You were given a gift of the playwright's view of what he wanted his work to be you take it and you run with it. If Larson needed Tom Collins to be passionate and to be desirable, there was a reason. It was my job not only to figure that out, but to build upon his vision.

Actually, it was playwright Billy Aronson, who wanted to write a musical version of Giacomo Puccini's La Bohème, that came up with the original idea for Rent. He believed that Puccini's opera dealt with themes and characters that were still relevant for the modern era, and that those areas could be accentuated by placing the action in modern-day New York City. In 1989 Aronson brought his vision to Larson; he fell in love with the idea and immediately envisioned what would become his masterpiece. "On a notebook page covered in research for Rent, Jonathan [Larson] also scribbled the lyric from Merrily We Roll Along 'We're opening doors' and underlined it three times. Underneath it, he wrote 'why they won't ever sell out"' (Miller). Larson's concept for Rent then became "Hair for the '90s," and he wanted "to bring musical theater to the MTV generation" (Tommasini).

There is the camp that wholeheartedly believes that the text and playwright are holy. The ideology of everything being tied to the textual analysis and playwright's intended visions is a viable way to create the character. I believe that building a character to tell a story is a conversation, especially in theatre. Wherever the playwright leaves off, the actors, directors, cast, and the crew have to fill in the missing pieces. A community of people comes together and builds off of each other to create a story with multiple personalities and points of view. Of 
course, it is important to follow the playwright's intent but in Larson's case we must posthumously fill in the gaps. Rent is not a love letter to Larson; it is his love letter to the world he lived in, to New York in 1990, to his bohemian quest to uncover some artistic expression inside of him. He populated his love letter to the world with outside voices trusting that they could fill in those gaps; that they could build upon his story; that they could fill his music with the love and light only their expression could bring form to. It was not only the people around him who helped build the world of Rent but the generations of storytellers and artists who will keep him alive by building upon what he has given us. Ultimately, that is the task we are given as actors. Of course, we do create characters, we do bring text to life with our voice and with our actions, but most importantly we keep art alive, and we make the Bohemian immortal. 


\section{Character Research}

When building characters, it is important for the artist to examine how they look upon themselves. Personally, I find that a human subconscious, a human psyche, is made up of influences and experiences outside of ourselves, mostly out of our control. We rely on other people who have lived similar realities to shape our current one. These are our mentors, our friends, and more currently in modern history, social figures, artists, or celebrities that we look up to or idolize. We shape ourselves to be the best version of what we see on an everyday basis. So, when building Tom Collins, it was important for me to find figures in his life that he may have looked up to, that he may have emulated, whether subconsciously or very intentionally.

My version of Collins is obviously taken from my own experiences and subconsciously observing art and people around me. I based his influences on two very distinct outside figures that most likely would have shaped him: the first, more character driven, text-based, mainly focusing on his intellectual pursuits, social and political ideologies; the second, more musically inspired, diving into the character's rhythms and vocal range and all-around musicality and how figures in his life would have influenced that voice in him. Allen Ginsberg, being the first, was a bit of a challenge to connect to Collins initially, but researching him more and already having ties to his poetry personally he seemed like an obvious fit. When discovering Collins musically, Tom Waits never crossed my mind until I did background research into what Jonathan Larson saw in Tom Collins. 


\section{Allen Ginsberg}

I really solidified one of Collins's main historical influences as being Allen Ginsberg when I stumbled across a book of his letters and correspondence. A few years earlier, I had watched a film starring Daniel Radcliffe, Kill Your Darlings, that dramatized Ginsberg’s collegiate pursuits at Columbia. Thinking about that film, I decided to look more into who he was as a person, romantically and politically. I was drawn to his lack of romanticism in his relationships. How he instead found passion in community and channeled it into his art to change the world around him. Tom Collins is an anarchist, a gay man, a professor of Philosophy, and a "comfortable home for the Acquired Immune Deficiency Syndrome” (Larson 12). He reminded me a lot of a young Allen Ginsberg, the famous "guru of counter-culture, who shattered conventions as poet laureate of the Beat Generation and influenced the next four decades of art, music and politics" (Allen Ginsberg 1). I like to imagine that Collins drew some inspiration from Ginsberg in being a prolific anarchist on the rise.

When I found The Letters of Allen Ginsberg in the library, it all clicked together. This specific correspondence really struck me as something Collins would be drawn to. In it, Ginsberg explains his poem "Howl” to Richard Eberhart, who initially criticized the work. His patience, yet underlying passion in his defense of his own work, sparked the realization in me that Collins had probably sat down and read these very same letters:

\section{Allen Ginsberg [San Francisco, CA] to Richard Eberhart [New York, NY]}

May 18, 1956

The title notwithstanding, the poem itself is an act of sympathy, not rejection. In it I am leaping out of a preconceived notion of social "values," following my own heart's instincts — allowing myself to follow my own heart's instincts, overturning any notion of 
propriety, moral 'value,' superficial 'maturity,' Trilling-esque sense of 'civilization,' and exposing my true feelings - of sympathy and identification with the rejected, mystical, individual even 'mad.' I am saying that what seems 'mad' in America is our expression of natural ecstasy (as in Crane, Whitman) which suppressed, finds no social form organization background frame of reference or rapport or validation from the outside and so the "patient" gets confused thinks he is mad and really goes off rocker. I am paying homage to mystical mysteries in the forms in which they actually occur here in the U.S. in our environment. (qtd. in Ginsberg and Morgan 131)

I imagined Collins carried around a book of poetry in his favorite jacket, famously stolen at the top of the show. While I never actually had a physical book of poetry with me during the performances, imagining Collins with a book of gay poetry in his pocket was an image I loved having in my head. It seems like just the type of drug-fueled rant that would get him riled up to fight the classist, cis-white, patriarchal government that ran the 1990s United States of America, since "Kaddish, one of [Ginsberg's] most famous works ... was written in his Manhattan apartment, stream of consciousness-style, fueled by a combination of amphetamines and morphine" (Allen Ginsberg 2). When framing a character described as a "vagabond anarchist," Ginsberg, is ripe for the metaphysical picking. Just reading his poetry spotlights his musical, rhythmic qualities. I also have a personal respect for the bohemian: I always read "Howl" every time I open my computer because I have it as my desktop background. He saw pain, suffering, poverty, and he lived his life fighting against hate and changing the minds of many. Ginsberg is the man Tom Collins wishes he could be, filled with rhythm and passion and yet still able to care so much for the fate of the world around him. As Ginsberg himself frames the idea in the opening lines of "Howl": 
I saw the best minds of my generation destroyed by madness, starving hysterical naked, dragging themselves through the negro streets at dawn looking for an angry fix, angelheaded hipsters burning for the ancient heavenly connection to the starry dynamo in the machinery of night, who poverty and tatters and hollow-eyed and high sat up smoking in the supernatural darkness of cold-water flats floating across the tops of cities contemplating jazz" (Ginsberg 9)

There is a time in every actor's process where everything just clicks. For me, it was when I read this quote from one of Ginsberg's letters about mercy and self-acceptance. Whether it was something about the word "angel" jumping out to me from the text: "the ability to see and love others in themselves as angels without stupid mental self-deceiving moral categories selecting who it is safe to sympathize with and who is not safe" (qtd. in Ginsberg and Morgan 132). Or the aggressive altruism that shaped the life of this poet who was able to write about it and still fight so hard for what he believed, I honestly could not say.

In a way, I feel like this is the description of what it is like to be a father, something Tom Collins never has the chance to be, at least in the traditional sense. But to him the traditional sense was never really his bread and butter. He makes a home wherever he is spreading his ideas and his love to the people around him whether they be his former roommates or his students or the person who teaches him how to love and be cared for. 


\section{Tom Waits}

In trying to find advice on performing Rent, I stumbled across an article written by Anthony Tommasini who had done an interview with Jonathan Larson. In the article Jonathan Larson tells Tommasini that Tom Collins is, "a sort of jazzy, Tom Waitsy [sic] kind of guy" (qtd. in Tommasini 2). It was not much information but having a physical person to model Collins off of directly was more lucrative than a whole page of notes about who this person needed to be. Finding the connection between Tom Collins and Tom Waits helped me realize the tone of Collins musically.

I began reading more about Tom Waits, not being a fan of his music before my research process. I thought a lot of his music, specifically the more romantic songs, were very similar to the style in which Collins's music was written. I even read that Tom Waits' persona when he was performing his music was not very earnest, which is honestly equivocal to a lot of lyrics in both "Santa Fe" and "I'll Cover You." Both songs speaking on life and love but through a veil of word play and humor, always dancing around the point. In "I'll Cover You," his duet with Angel, his love interest, he starts off by shutting down the words of praise that Angel gives him. Never allowing their words of protection to land on himself, and instead mirroring a lot of the same images back towards them:

\section{BOTH}

I think they meant it

When they said you can't buy love

Now I know you can rent it

A new lease, you are my love 
On life, be my life

Just slip me on, I'll be your blanket

Wherever, whatever I'll be your coat

\section{ANGEL}

You'll be my king,

and I'll be your castle

\section{COLLINS}

No, you be my queen, and I'll be your moat" (Larson 44)

In "Santa Fe," he jokingly hints of a life that he could run away and create, knowing full well he could never leave his home without being drawn back. The narrative he weaves in the story about leaving New York (and teaching) behind to pursue whimsy and relaxation working at a mundane job in a less exciting state is vaguely similar to Tom Waits' "So Long I'll See Ya", in which Waits envisions leaving home, peppered with lines of vocalization between the choruses and the verses.

Well bye-bye-bye, well bye-bye-bye

Sing bye-bye Shooby-do-bye-bye

Gotta skeet-skat outta here, skeet-skat outta here

And mamas in the kitchen, daddies on the phone

And nobody knows what's going on. (Waits, "So Long I'll See Ya” 1:00-1:32) 
I do think that Collins's journey takes him from the place of Tom Waits' lack of earnestness to a place of deep care and connection to his chosen family, but the jumping off point of Collins's journey in the show's narrative can be summed up with a description of Tom Waits before being interviewed by Tim Adams for the The Gaurdian: "He gives the impression of being in a state both of constant startled awareness, and vague puzzlement at the world" (Adams 1).

Tom Waits' gruff voice and sorrowful Jazz riffs are echoed most notably in Collins's verses of "I'll Cover You (Reprise)." My inspiration when preparing for the intensity and care that came with performing this number came from Waits' "Come On Up to the House."

Well, the moon is broken and the sky is cracked

Come on up to the house

The only things that you can see is all that you lack

Come on up to the house. (Waits, "Come On Up to the House" 0:00-0:31)

The two songs share similar images of physical shelter and protection as allegory for love and acceptance. Though Larson's composition came first, the parallels to the plot of the show are chillingly similar. Tom Waits' idiosyncratic style is very much in place within the first few lines of the song, differing from the original "I'll Cover You" which has a very structured sound and note progression that almost mimics Angel's percussive proclivity. 


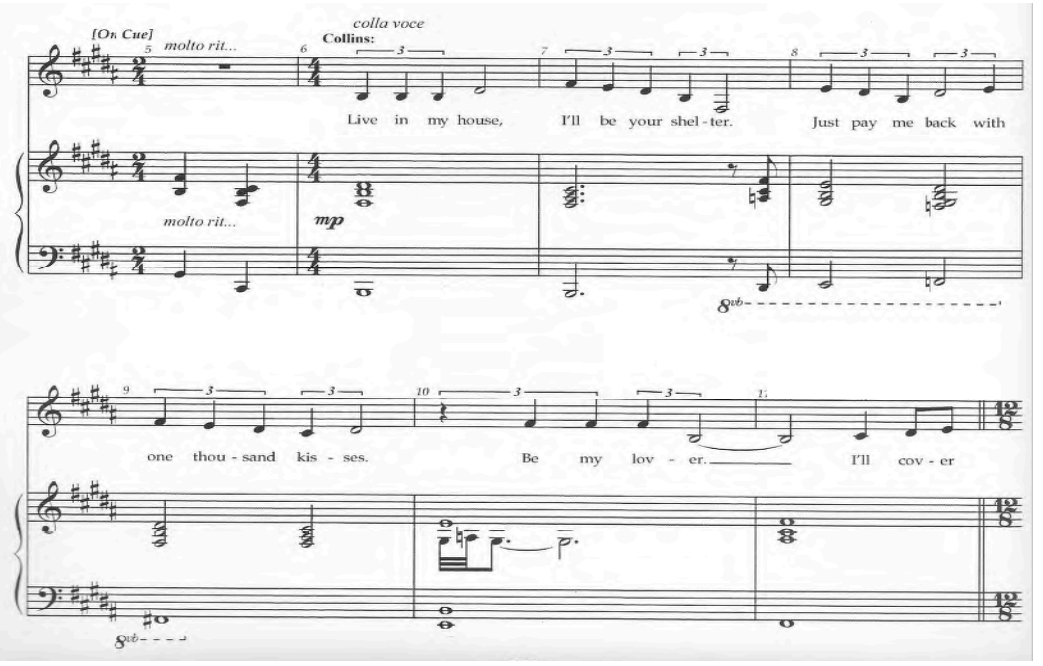

Figure 1. Larson, Jonathan. Rent. 1996. Screenshot. Musical Theatre International.

What I found most interesting about Waits is his attention to detail and his love of play, "I try to pay attention to what people are doing the moment they come into the room. If they are just goofing around before we begin that may be the best thing they do all day. I have to be waiting" (Adams 1). When creating Collins's inner life, I saw that his nature was naturally chaotic and fun, "Ran naked through the Parthenon. . . . talking not about Heidegger, but wine . . . . I rewired the ATM at the Food Emporium" (Larson 21, 42, 113). I struggled to find the balance between radical and professorial until I learned more about Tom Waits and how he separated his performance persona with the caring, fun-loving individual he brought home to the people in his everyday life. That use of code switching happens to us all, helping us compartmentalize our relationships and responsibilities, but it is difficult to think about characters as living and breathing people until the actor finds some sort of reality to root those traits in. 


\section{Text Analysis}

The examination of the text itself is an important part of any actor's process. Thorough reading and a deep dive into the workings of the script and the music when specifically dealing with a show that is mostly sung through is vital for this success any performer. The story that is being told must be explored backwards and forwards. Analysis of the text allows the actor to unearth a certain amount of specificity needed to perform and allows for the marrying of previous dramaturgical work including historical significance and the playwright's biographical information with the performative text.

Rent presents itself as a retelling of Giacomo Puccini's La Bohème more than a hundred years after the setting of the opera. Book writer, composer, and lyricist, Jonathan Larson, parallels 1990s Lower East Side, New York to 1830s Paris, replacing tuberculosis with AIDS and Italian arias with a melting-pot of musical genres from Jazz to Tango. Larson explores a year in the Bohemia that is the writers, filmmakers, activists, and survivors of New York City's Lower East Side. His pastiche is clear to critics:

[Larson] found different types of contemporary music for each character, so the hero [Roger] in Rent sings in a Kurt Cobain-esque style and the street transvestite sings like De La Soul. And there's a Tom Waits-esque character. The American musical has always been taking contemporary music and using it to tell a story. (Istel)

Although the show is presented as seen through the lens of the character Mark Cohen, the structure of events follows an ensemble of relationships with Mark navigating the outside, looking in. Mark is never the central protagonist of the story, but merely an observer on his friends' lives as he completes his dream of becoming a documentary filmmaker. The musical mainly explores how the relationships that Mark observes fluctuate in the span of a year, and the 
audience is allowed specific insight to the inner workings of each character through song and their relationship with each other.

The story of Rent is based upon both the opera La Bohème composed by Giacomo Puccini (with a libretto by Luigi Illica and Giuseppe Giacosa), and its source material: Scènes de la vie de bohème by Henri Murger. While Scènes de la vie de bohème is a collection of stories about the life of people following the artistic and bohemian lifestyle, La Bohème creates the plot and characters that serve as the basis for the story that Rent tells. Characters, themes, and some plot points remain the same between the opera and the musical, such as the character Mimi and the scene in which she meets Roger and asks for him to "light my candle" (Larson 11). While Mimi in Puccini's opera is not a stripper with AIDS and a drug addiction, there are similarities in plot points between the two characters. In La Bohème Mimi dies, giving the opera a much more morose feeling at the end as opposed to the positive feelings that the audience can have at the end of Rent which is centered around hope in the face of adversity. Another key difference between the opera and the musical is the characters that are key figures in Rent such as Collins, Angel, and Benny, are supporting and side characters in La Bohème with very little impact on the overall story that is being told. Rent would not be the musical that it is today without the story of Collins and Angel, with Angel's death serving as a pivotal moment in the entire story, bringing the ensemble back together. The characters are present in the opera but are reduced to singing a couple of lines and never really progressing the plot.

As opposed to the mosaic of storylines that are contained within Rent, La Bohème has a more straightforward plot. A great deal of material lives within Rent as opposed to La Bohème due to its pacing and ambition, like the thumping of the New York City streets. While there is 
obvious inspiration and similar plot progression, Rent sets up a different, more engaging experience by connecting the human experiences presented in both pieces across time and locale.

The first theme that permeates the year-long rock opera that is Rent is the theme of clawing to survive as an artist in a world that values capital gain over artistic fulfilment. Even though the passions of each character are different, the overarching hope and struggle it takes to live truthfully as an artist remains.

From the title song, to "What You Own" in the second act, Rent discusses the value of being true artistic self despite being faced with the reality that it is impossible to maintain their lifestyles without giving in to a larger corporate machine. Mark takes a job as a tabloid news reporter and hates every minute of it, eventually quitting due to the lack of artistic value that the current projects that he is working on have. The perseverance and stubbornness of the artists is the fuel that Rent uses to drive its plot forward.

The main theme shared by La Bohème and Rent focuses on sickness and what it means to carry — and live with_— a transmittable disease. Both pieces have storylines that are centered around characters that are afflicted with disease, and the plot revolves around the development of those diseases and the reactions of the other characters around them. Mimi in the opera has what is believed to be tuberculosis, while Mimi in the musical as well as Roger, Collins, and Angel all have as well as populated members of the ensemble suffer from AIDS. Angel's death is a key moment of character development for every main character in the production, creating grief and tension as well as bringing other problems to the forefront in songs like "Halloween" and "Goodbye Love." In Rent the theme of disease cannot be described better than with songs like "Life Support" and "Finale B" covering the duality of feelings in regard to living with disease. From "Life Support:" "There's only us. There's only this. ... Forget regret or life is yours to 
miss. No other road. No other way. No day but today" (Larson 21-22). This shows there is a more positive outlook shown by some of the characters such as Collins and Angel, regarding their illness. They live with a disease they know will overtake them in time not only destroying their body but the ability for them to find intimate relationships with others due to the sexual nature of the transmission of the disease. In fact, the first time that AIDS is mentioned is when Angel confronts Collins in "You Okay, Honey." In Rent, Jonathan Larson talks about learning to live through hardships and disease, whereas Puccini muses about the inescapable grief involved with losing someone to the uncontrollable.

While both pieces have similar characters, plot, and themes; the way that each piece goes about conveying thematic elements shifts radically in tone. Rent expands the number of characters we get to see living with disease as well as gives a more hopeful tone to the notion of contracting illness and building community around struggle. That community is shown most clearly when the company of Rent sings in "La Vie Boheme B," "to people living with, living with, living with not dying from disease" (Larson 45). Showcasing the attitude Rent has towards people with AIDS is in direct contrast to viewpoints in La Bohème that culminates in the harshness of nothing being able to be done after a diagnosis.

Collins is the prime example of living and thriving in the face of such adversity. Living with AIDS, finding love, and still pursuing his passion of teaching and nurturing is the most inspiring aspect of his character. While he goes through the same amount of struggle as many of the other characters, Collins's journey is not to find himself, but to inspire his found family to find themselves. Along the way, he learns to be loved and in coming across that realization, loses the catalyst to those feelings. Besides that, he needs to support the people that Angel wanted and worked so hard to bring together. He takes up the mantle of father, of lover, and of savior, 
constantly entering scenes with money or gifts for Mark and Roger and even being the one to rush to Mimi's medical aid by calling 911 in "Finale A." His heart shines through, whether picking up his relationship with Roger that had gone stagnant after Roger secluded himself for two months, or reaching out a hand to has community by participating in Life Support, a therapy group. Archetypically, Collins is the Nurturer. He is a caregiver, an altruist, not necessarily someone who can provide, but always willing to give up what he needs for himself in order to help others succeed. He is the glue that holds the ensemble together. 


\section{Actor's Process: The Walkthrough}

\section{Finding Tom Collins}

Being creative can be one of the most joyous experiences. Inspiring creativity? That is pure joy. What was interesting about this process is that it allowed me to act as more of a mentor and teacher more than any other show I had worked on previously. The cast was populated with mainly first- and second-year undergraduate Musical Theatre majors; in fact the characters of both Roger and Mark were played by two first-year students, only a semester out of high school. ${ }^{6}$ Collins felt the need to protect both of these characters and nurture them in his own right. It was a kind of blessing to be able to take up the same kind of teacher/mentor role with the two actors outside of the show as well as on stage. The COVID protocols we had to follow during the rehearsal process dictated that we were not able to congregate in groups larger than sixteen within our smaller rehearsal theatre, the Vivian Davis Michael Laboratory Theatre-a proscenium theatre space that usually houses fifty to seventy-five audience members — which made each rehearsal more intimate as we mainly worked with the principals first and worked the entire ensemble into the space in chunks. We also had to get PCR tested every Monday, Wednesday, and Friday and because I walked past Christopher and Eli's dorms on my way to get tested, I was able to connect with them on our short walks to the testing facility in the campus's recreational center. In fact, because another one of our COVID protocol practices had had us traveling from our dressing rooms at the CCAC on West Virginia University's campus to our stage at the Hazel Ruby McQuain Amphitheater-completely off campus and outside as to allow us to perform the show unmasked - and I was a graduate student of the university, insured by

${ }^{6}$ In our production Mark Cohen was played by Christopher Clausnitzer and Roger Davis was played by Eli Nygaard, both first year BFA majors at West Virginia University 
them to drive vehicles rented by the university, I drove one of the three transport vans to and from the amphitheater with several of my cast members. There was a very nurturing quality in having to keep at least six other cast members safe every night as we made our way to the stage and back again.

Through my connection with the cast, I quickly found Collins's voice. He was a rebel, a being of chaos, but at the same time, wholly a nurturer and a teacher. Even his relationship with Benny had the legs of a mentor, albeit a disappointed one, but still always nudging him in the direction Collins thought was right. In this excerpt from the journal I kept on the rehearsal process of Rent, I highlight how I was feeling on the nurturer side of Collins:

I am finding a strong insight into how Collins feels about the world, how he loves everything but knows how everyone thinks needs to be dismantled. Expanding more on this, I think this a strong parallel to Colline in Puccini's La Bohème. he is a philosopher who cares for others' minds. They are both nurturing presences, trying to coax the best out of their friends by challenging them loudly (an interesting juxtaposition). How kismet that I'm thinking about this after learning "La Vie Boheme" (Khoshgam).

The climax of Collins's character arc is his solo in "I'll Cover You (Reprise)." It was important for me to nail this aspect of the character before moving on to defining him in the rest of the story. This solo was the cut of the song used in his call-backs for the roll of Collins, and when singing it I have always felt that it was connected to loss and to the emotional attachment he felt for the character of Angel. Through my research, I found that it dives much deeper; there is fear behind the words that he sings, fear of losing more than he has already lost and, through the song, he uses text both Angel and himself sung to each other in the original "I'll Cover You" to express something deeper than intimate love: learning how to love a community. I remember I 
first came to this realization when I read a passage about Jonathan Larson's death in Anthony Rapp's memoir Without You. This is the passage I will always think of when I hear "I'll Cover You (Reprise)":

And at last, Jesse [L. Martin] slowly took his place at the edge of the stage, clutching his coat. His kind, handsome face illuminated only by a pin spot, his big brown eyes deeply mournful and loving and humane, he began his song to Angel and, tonight at least, to Jonathan.

Live in my house

I'll be your shelter

Just pay me back with one thousand kisses

Be my lover

And I'll cover you

The room was completely silent and still, except for Jesse's resonant, heartbreaking voice and [Tim Rice's] accompanying, soulful piano. More and more tears fell down my face, and I could feel my fellow cast members crying too, which again made me cry all the more. I couldn't even bear to look out at the house, because I knew what I'd find there, and before I knew it, it was my turn to sing with the rest of the ensemble, and I joined the line at the edge of the stage and did my utmost to produce some kind of sound. But no sound wanted to come out, my throat was choked. I saw the sorrow in the faces of the audience members in front of me and my heart broke all the more-I could not believe that we were here right now singing this song for such a 
terrible reason — and I tried to sing through my sobs, but I could only manage a few notes, my voice croaking through the climax of the song:

Oh lover I'll cover you

Oh lover I'll cover you

Jesse [L. Martin] amazingly held us all together, never wavering, and ending with a wrenching wail that echoed through the theatre, until the light on him faded to black, and the audience exploded once again with an extraordinary, cathartic cheer. (Rapp 133)

Jesse L. Martin held them TOGETHER. That is the biggest clue of the song. Collins is not singing to Angel, he is singing to keep everyone together, it is his love song to his friends. "I know you can rent it" (Larson 97) means he knows the promise to love will come to an end, but while they are around, they will shelter each other with that love. 


\section{Rehearsals}

This section, as well recounting the hectic and sparce rehearsal process, contains the few journals I kept. I was just coming out of filming King Lear, and I thought it might be helpful to write down my shift in focus in order to break out of the story I had just spent months living in. It is important as an actor to explore during the rehearsal process. In my journey as a training actor, I had always learned do your work outside of the rehearsal hall and bring to the rehearsals the ideas you want to work on. This process worked a little differently than most, due to the COVID protocols requiring us to be masked inside and restricting the amount of people in the rehearsal spaces. I was stretched for time in both pre-rehearsals and during the rehearsal process. Adding on the fact that I was completing a full load of classes in the Master of Fine Arts in Acting program that were supposed to have been completed during the fall 2020 semester but pushed to the spring 2021 semester because of COVID class restrictions. These factors made it difficult to bring to the rehearsal hall the fuller concepts that I knew I needed to bring to my character work in order to provide a fair playing space for the rest of my cast-mates. Not only did I start this rehearsal process with a very limited idea of who Tom Collins was I also was coming in each night with limited knowledge of technical aspects I needed to rehearse the music. I had never been classically trained nor did I have the ability to read and analyze musical scores as well as a lot of my younger cast-mates. Going in, though I was the most experienced actor, I felt like I was the least experienced musician of the group, and most of the beginning of the rehearsal process was intensely technical. Luckily, I was surrounded by a cast and the production team who knew not only the limitations of the process itself but who were very open and accepting up the way I worked and the handicaps I needed to learn and digest the music. 
Before we even had our first rehearsal, the only research I had time to complete, besides the historical and the biographical, was listening to different cast recordings of the Original Broadway production and the live television version of the musical that was broadcasted by Fox in 2019. What I did not know was that these two iterations of the same story were very different, and by listening to the sparse original Broadway cast recording - the recording omitted songs used as transitions - and the full live television cast recording I had two ideas of the show in my head.

My first rehearsal was peppered with a limited number of cast-mates. We had all joined a Zoom call early in the semester to meet with our new director, Professor Leland Blair, and I were nervous coming into the space knowing very little about the process, the cast and the new director's vision. Luckily, I had no time to think about those nerves; our rehearsal process had been pushed from early February to late March, with the expectation to perform on April 21, 2021. So, when I wrote down that I had "No expectations yet," I was truly coming into the process blind. I was introduced to the people I would interacting with most in the process for the first time. I was able to physically interact with the human beings I would be sharing the stage with, most importantly, my love interest and counterpart, Angel.

Meeting Joseph Solmor, the actor playing Angel, was a great experience. I think that everyone is fighting through those first day nerves, so he is a little quiet (compared to me at least) for now. Christian, the actor playing Mark, is incredible! It is a joy to be back, singing with people again. I know we don't have much time to put the production together, but if everyone pulls their weight like Joseph and Christian then I think we have a good shot at putting this thing up!" (Khoshgam) 
It was a definite rush getting back to live theatre after leaving the world of film. I was able to stand around and have conversations with people I knew I would see every day, as opposed to sitting around and waiting for my shot in the dressing room or being called to do nothing and still wait in the dressing room. I started off working with students who had never performed a mainstage production at WVU. I connected to them, nervous about performing my first musical on the mainstage. It was also a huge relief that R. J. Nestor was hired on as our Vocal Director. R. J. had been my private vocal instructor for the past two years, so it was a comfort to have someone who knew my vocal instrument more intimately than myself in the room.

There is a comradery between the company that the expediency of the process has spring boarded into action. Not only do the three of us [Joseph, Christian, and me] seem to be getting, but Lee, our director, Sunny, our Stage Manager, and R.J., our vocal director, have joined in the fold. A lot of the rehearsal was populated with a healthy amount of goofing around. That may not seem like a big deal, or even remotely productive, but community has always been important to me. A strong ensemble, a strong community helps me settle into a role without fear or judgement. I think I'll be able to explore Collins fluidly with this group, even with the time crunch. (Khoshgam)

The next rehearsal added more of the cast in the room, We had a majority of the cast in the room. We learned the choral parts to 'Rent,' 'Tune Up B,' and 'Seasons of Love.'” I felt like I was finally starting to see a picture of the world we were trying to create. The interesting part about starting to see this specific picture was the fact that I knew our director was going on that same journey with me. Usually, the director of the production has time to plan and develop a concept for the show before casting even begins, but Professor Blair was just as in the 
dark as I was. His ideas about the show hinged on how well we worked together as an ensemble, and how fast we could learn the specifics of the music, for it was the backbone of the show. Our work as a group felt like a living, breathing organism. We were all growing together and bouncing ideas off each other, and it was exciting to see our director observe us and take notes on our processes.

I have been a part of many processes that have felt clinical and unrelenting, especially when doing musicals. There is a certain amount of perfection that is demanded extremely quickly when learning a musical because the process hinges on whether a performer can keep time and keep pitch along with memorizing lyrics and living in a set of imaginary circumstances. A lot of perfection to be demanded. A daunting task that isn't at all aided with a judgmental or disjointed ensemble, but I am finding genuine connection in this group.

It was a massive weight off my shoulders. I didn't feel like I had to be some sort of leader being the only graduate student in the room because I could see the director floundering with us.

The energy keeps building. It's easier for me to live as Collins because I have genuine connection with the group. I thought a lot about community last night, and I can feel that strong connection with these people. We are all focused on the goal of making art, and it feels natural in a way. (Khoshgam)

There was an exciting amount of learning to fail in the process, and in failure there was an immense amount of growth. We banded together and created a community of artists willing to do what they love for the sake of doing what they love as opposed to following director's vision. It felt a lot more like divining a performance than it did a rehearsal process.

Later than I expected, that is to say, when we were halfway into the rehearsal process that had already been pushed back by more than two months, we learned that the blocking of the 
show would be more like a zone-to-zone concert version of the musical rather than a fully staged production. The stage was mapped out into 16 different sections that were all six-feet apart from each other so that we were able to stay within CDC guidelines. Blocking the show, however, was not stagnant by any means. While the actors did have to stay unmasked, twelve-feet away from each other at all times, when we were masked, because we were outside, we were able to get in close proximity of each other. Obviously, we just felt lucky to be able to perform the show in any capacity so moving from zone to zone became our new normal without any complaints or resistance to the process. As a company, we were together, and I think that really solidified the community that we were able to build on stage.

We quickly began blocking our version of the show and it became clear to me my shortcomings as a musician rather than an actor, "Though I am the most experienced, I feel out of place. Out of my element? It has been a few years since I have been in a musical, and I forgot how much information there was to learn" (Khoshgam). I didn't have the musical theory training that the Musical Theatre majors, even the younger ones, had. I felt like I was unable to count a lot of the difficult rhythms that populate the entire show and mimic spoken dialogue, and I didn't think my voice was as trained as many of the students in the rehearsal room who had been in voice lessons for many years. Focusing too much on my failures begin to impede my acting process. I had to find some way to remind myself what really mattered when creating with other people. Intellectually, I knew that I was not the only one focused on myself, that everyone else in the cast was concerned about their own parts and shortcomings, "I think it's important to observe this discomfort. Where is it coming from? Being unprepared? How prepared are you supposed to be? We are just starting to learn. It helps no one if I am fixated on comparing my level of preparedness to others." "But I just could never shake the feeling that I wouldn't "get out of this 
slump," especially in the time that we had to produce the show. There is a time and every actor's process with every show that they are thrown into the deep end, and they have to either sink or swim. I think that is the defining moment of their character creation when they must make strong choices in order to survive the intensity of the process. That moment for me was the first time we had to run all of Act I.

Usually there is a grace period where we are able to run blocking with our scripts in hands but this being a severely shortened process, the first time we ran act one was completely off book and it was terrifying. I did not feel like I was ready, and I remember all that day I was finding every spare moment to sing my songs and think about my relationships. I found that most of the time I had to work on the roll was when I was traveling in between classes, going to and from buying groceries, or doing other chores mostly because I walked everywhere. Living in Morgantown, WV, I didn't think it was pertinent to purchase a car to get around the small town especially, when I was capable enough to walk eight to ten miles a day, and the distance between my apartment and our rehearsal space was less than two miles away. This gave me ample time to sing to myself and think about my process, especially when I could take a walk with Tom Collins anytime I needed to mull over ideas and my shortcomings travel-wise became one of my most used tools in finding who this professor of "computer-age philosophy" really was.

When it actually came time to run the first act off book, I was able to make it through without too many hiccups. Unfortunately, I realized I was forfeiting my relationships on stage to the technical aspects of the show itself, just because the music and timing were so important to telling the story in fact it was the only thing that my character used to tell the story. As an actor I had always been praised not on my inherent ability to take the stage but in my ability to give my attention fully to my fellow scene partners and this was one of the first times in my acting career 
that I could tell I was not giving my full attention and it bothered me. I could tell mainly in my scene partner, Joseph that I was not fully receiving and responding to his sense of play in the scene and that wasn't fair to him. I did notice that the way we approached our intimacy was very different, and at that moment when I was thinking that over, I realized that the relationship with Angel was this source of change and epitome of performance and that Collins was very thoughtful and nurturing.

There are times when I feel like he is upset that I am not giving him the sensual energy that he is throwing my way. I think that can be an aspect of ANGEL that COLLINS falls in love with. She is performative and her life is her final show before she goes. I think Collins can see how hard she pushes them to be a family/her ensemble and tries his best to be "sexy" for her. Let's lean into Joseph's choices and build upon them. (Khoshgam) When I made that decision not to shy away from Joseph's advances as Angel, I found an interesting sense of play through the entire show. It was never Collins's job to be perfect or to be the one in his relationships to make the right choice every time. He is a rebel, a being of growth and change. I realized that my shortcomings in developing his relationships were coming from my need to be perfect in every aspect of the performance, but if Collins's identity is tied to change and growth then there was no need for me to have a perfect performance. I needed to do what he did: fail and still look after the people around him. He was expelled for his theories, contracted AIDS in a time when it was considered a death sentence, and had to steal from ATMs to survive. After that realization the performances started to turn a corner, or at least my perception of them became a lot less critical: 
Great first run! I found a good moment of connection with Joseph. Leaning into those moments of performance has really helped me find an appreciation for Joseph and an undying admiration of Angel. (Khoshgam)

There is a level of existential dread that is always present in art. It is, in fact, one of the many ways we spend the time we have. We have to work to be fearless, work to enjoy the process and the time we get to share with the community we build out of our company. The most important lesson I learned about being an actor during the process of rehearsal for Rent was that we must first allow ourselves to be human in order to be more than ourselves. A lot of what I discovered about Tom Collins, I discovered about my personal life, "For him and me, everything is a lesson. Whether we are the ones teaching or learning, every moment of life is a lesson. I don't think I have related so much on a phycological level to a character," I will take a piece of this character's inner life with me everywhere I go. 


\section{Walking with Collins}

An actor's process is sacred, but if it is not everchanging it becomes useless. A metaphor I have always used to describe that process is the "toolbox." In fact, the very first conversation I ever had with Professor Jerry McGonigle, the Head of Graduate Acting, when I was interviewing for the graduate program here at West Virginia University was about building up my toolbox as an actor. An actor can always add more tools to their kit, and the tools they use are not necessarily always the same for every role. We use the right tools for the right tasks. This section will examine what tools I used to prepare myself for the production and how well those tools served me in the process.

My actor training started from the basis of the Stanislavski Method. Konstantin Stanislavski is credited with being the father of modern acting theory; his work is the foundation of many acting theories I have picked through to procure tools for my toolbox. More importantly, his examination of what he calls the Given Circumstances of any show are my foundation to building a character. Stanislavski's idea of Given Circumstances states that to understand the inner life of a character you must first know their outer life. It is essentially the reverse of world building, the actor takes apart and analyzes every aspect of the playwright's world, the setting of the play, or as Stanislavski puts it, "The Environmental Facts" are broken into six categories:

1. Geographic Location: The specific area in which the play takes place.

2. Date, year, season, time of day.

3. Economical (sic) Environment: The character's relationship to wealth

4. Social Environment: values and societal beliefs.

5. Political Environment: relationship to a form of government 
6. Religious environment: controls based on religious beliefs.

-all the circumstances that are given to an actor to take into account as he creates his role (Stanislavski 43).

This form of textual analysis helps to ultimately figure out the reason or how a character came to be. In the time crunch of trying to come off filming King Lear, in which I spent the good part of two months analyzing text and doing table work, this process of finding Collins's Environmental Facts was more of a working discovery than anything derived from paperwork.

Collins came from a very low socioeconomic background; he was a professor struggling to survive. He was always pushing the limits of society as well. For example, he ran naked through the Parthenon. His identity as a gay man with AIDS also pushed the social boundaries, especially being a student in the 1980s. His social identity is tied with his political environment as well. He greatly fought against the capitalist structure that oppressed him and all of what he tries to instill in his students. The hardest thing to find was his religious environment because there were not any explicit mentions of his religious beliefs, yet when he found love in the character of Angel, "An angel of the first degree" (Larson 12), there was a pseudo-worship in the power of that love. Even after contracting this disease that impedes anyone from finding that kind of intimate relationship, that physical attraction without the scare of passing it on, or the scare of saddling somebody else with, at the time, what was considered a death sentence. All the elements of Collins's Environmental Facts inform the person that he grew to be by the end of the musical, and by examining and separating them from the show itself I was able to garner a clearer understanding as to how Collins moves through his world.

Chadwick Boseman-American actor and playwright known for his roles of baseball player Jackie Robinson in the film 42, James Brown in Get on Up, and T'Challa in Marvel's 
Black Panther — once said something that has continued to resonate with me: "[Acting] is really a blue-collar job. You work overtime, you sweat, you get hurt, you're an athlete, you're everything that is necessary, and you're pulling from things that most people don't usually deal with" (The Hollywood Reporter). Acting is psychological. Acting is physical. Acting is knowledgeable. It is an art form that imitates the lives of the people it affects, and like all art, it creates discourse and, in some instances, helps to mend societal wounds. It is a device used to send a message that rouses change. It is storytelling. The ability to truthfully convey a story is an artist's gift. To embody a character truthfully is an actor's gift. Taking on the role of any character is a challenging task: it requires skill and training and a whole lot of empathy. However, to continually tell a story for many hours or days at a time is a feat in and of itself. There is a standard of perfection one expects when living as a character. The audience must believe they have stepped into the real life of another person. That is why it is so important to condition oneself mentally and physically to do a role justice.

Mentally, I was able to sit with myself for quite a long time, due to COVID restrictions preventing us from socializing with people outside of our classes and company members in rehearsal. It gave me a lot of time to sit and think on the inner life of Collins and how he didn't have this time to muse about his own life, he was always moving: teaching, going to Life Support, and rebelling against the government. Specifically, I loved using the vocal technique of Dropping $\operatorname{In}^{7}$ to explore the psychological depth of Collins, a technique found in Kristen Linklater's Freeing the Natural Voice: Imagery and Art in the Practice of Voice and Language.

\footnotetext{
${ }^{7}$ Dropping in: The process was developed by Tina Packer and Kristen Linklater. It involves pulling specific words from a piece of acting text and asking a series of questions related to the word to the actor while they repeat that word back to the questioner. The goal is to create mental associations for each word, making them inherently more meaningful. Kristin advises, "Let the word fall into you: let your mouth feel it, let your middle feel it. Let it play on you. What is the word saying to you?" "Disgrace. When were you last in disgrace? Disgrace. With whom? Disgrace. Where does it sit in your body? Disgrace" (Linklater 110).
} 
Dropping In involves pulling specific words from a piece of acting text and asking a series of questions related to the word to the actor while they repeat that word back to the questioner. The goal is to train the actor's internal life to be full of the character's internal thought and feelings as much as possible by creating mental associations for each word, making them inherently more meaningful. Going through the process quickly so that "you are not stopping to 'think' or 'be sure' about your response. Bypass the head and let the question or instruction act directly on your solar plexus center with an instantaneous reaction out through any or all channels of your voice/body" (Linklater 36). To combat the fact that I was only limited to social interactions with my classmates and had a limited amount of time to actually socialize in between classes, work, and rehearsal, I would record myself asking Collins these questions. I used my time traveling to those classes, rehearsals, and to work to listen back on the recordings and drop into Collins. It added another layer to developing Collins's voice and the way he moved through the world. I was able to think with my whole body when I was taking my walks with Tom Collins. I started to expand on even just asking him questions and both rehearse his music while walking singing very loudly for anyone passing me on the streets to hear but there was a freedom to these walks, I felt like I was getting to know him in a very visceral way. Gradually, it became a major tool in developing Collins as a character, but it also became a daily ritual. Constantly walking with the character, living in his thoughts, and singing his music gave me the time to process and work through rehearsal notes in an active setting. It gave me a way to both exercise psychological and the physical parts of myself that it would require to play the role.

In my years of studying acting and developing my own acting process, a lot of what stuck with me were techniques from the teachings of Michael Chekhov. One technique I use constantly is that of the Imaginary Body. Oftentimes, actors focus on how they and their character are alike; 
the connection between myself and Tom Collins was very similar when I started to rehearse the role. Chekhov insists actors focus on the differences between themselves and the character. One way to do this is with Imaginary Body: "building" the body of the character for the actor to step into and inhabit. The practice requires an actor to feel a physical change in the length and shape of their body, to physically transform themselves into the character. Not only does this connect an actor to the movement of the character but it solidifies that an actor is always underneath this skin of the character that they were playing, that the character never becomes the actor, because it is always important for an actor to be able to step away from a role and think of it critically and analytically, like a third party editing a work of literature. Chekhov clarifies his Imaginary Body technique in his On the Technique of Acting:

Here again the actor has to appeal to his imagination. Let us say that he has to become, on stage, taller and thinner that he is in reality. The first step he must take is to imagine, as it were, another body for himself, create an Imaginary Body that is taller and thinner than his own. The next step will be a careful process of putting the actor's body into the Imaginary Body, trying to move the physical body so that it will follow the characteristic movements and shape of the Imaginary one. If the actor lifts up his imaginary long lean arm, he also moves his real arm within it. (Chekhov 100)

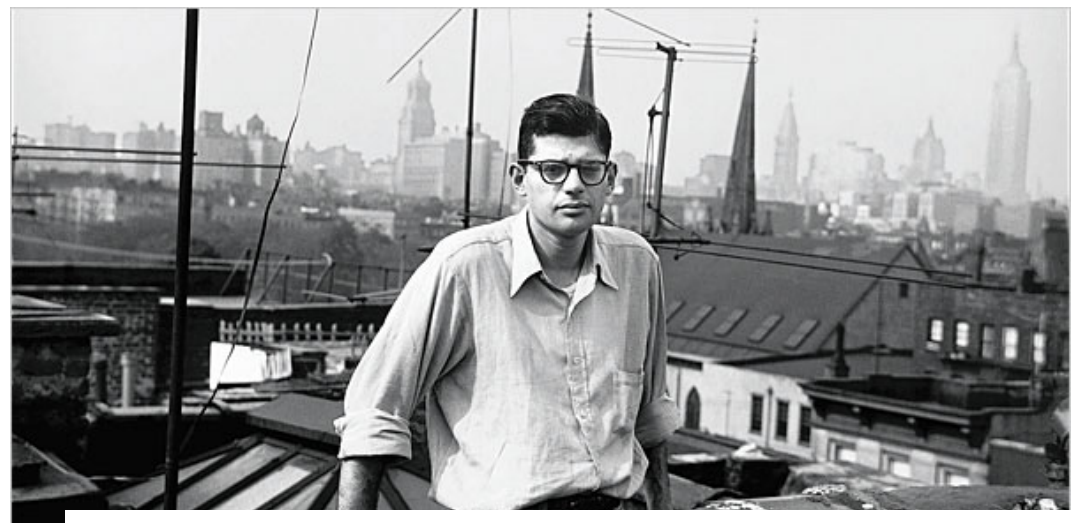

Figure 2. Burroughs, William. Allen Ginsberg on the rooftop of his Lower East Side apartment. 1953. Photograph. New York Times.
Pushing for bolder choices and clear differences between myself and the body of Collins, I used an image of Allen Ginsburg (Figure 2) to inspire myself when starting 
to develop my Imaginary Body. I first built the body directly in front of me. Starting off with the feet and moving upwards, the Collins I created was short and incredibly thin, he wore large boots, and ill-fitting pants that were too large for him, made of knock off denim material that felt very similar to a canvas bag. He wore baggy button-down Hawaiian shirts layered on top of each other and a large, almost trench-like coat where he kept an Altoids case of AZT medicine and a stone he took from the Parthenon. At this point, I was imagining Collins from costume sketches our costume designer, Professor Mary McClung, Director of Costuming, had shown me in my first costume fitting as well as images of Allen Ginsberg in his late twenties because Larson never gave a clear physical description of Collins in the text. After building a detailed and fully fleshed out image including fingernails, height, and weight, I walked around the creation, utilizing my five senses to fully explore the differences between him and him. I felt the texture of the clothing, smelled for cologne, and even reached into his pockets to find those treasures. After a full exploration, I positioned myself behind the Imaginary Body of Collins. It was like I was stepping into a Halloween costume: I unzipped the back of the body and stepped into the Collins I had created, making appropriate physical adjustments filling the body, and finally closing my eyes. The next breath I took was always that of the character's, and when my eyes were opened, the inner life I had developed for Collins came flooding in. I would then go through lines and music as the character to explore a range of choices and reactions I could take into rehearsals. Using Chekhov's Imaginary Body, I was not only able to expand my exploration of Collins by stepping outside of him and observing him as a third party, but I was also able to develop a fast and safe way to physically and mentally enter the space I needed to perform the role. So much of this technique is developing specific physical triggers that put a lot of weight on the physical memory of the body, using physical triggers to unlock the psyche of a character in order to jump 
into the role at a moment's notice. Stepping into the Imaginary Body of Collins became another pre-show ritual for me, as well as a tool to rehearse the part. 


\section{Performance \& Reflection}

In this section of the document, I will recount the performances of Rent and analyze how each was affected by my preparation and other discernible factors, including audience response, social and political implications, and the support of the University and faculty of The School of Theatre \& Dance. I will also explore the pitfalls of each performance, how the show grew or regressed night after night, and the effect these performances had on myself and my active process.

First, stepping into the space at the start of our tech rehearsals was a jolt of energy and hope that the entire cast needed. Throughout the entire process there was wavering confidence and our ability to actually perform the piece that we had worked so tirelessly to construct. Being in the amphitheater for the first time allied some of those fears. The space was large, almost resembling that of a theme park Amphitheatre. The stage was framed by a large lighting rig and our scene house, designed by our Scenic Designer, Professor Robert Klingelhoefer, was a 1990s urban street scene made up of a large platform the orchestra played upon. The platform housed two entrances in the middle of it, making a small backstage area for quick-changes and exits. The rest of the stage was bare, consisting of the numbers one through fourteen, spaced six feet apart because our COVID protocols only allowed us to sing, unmasked if we stayed twelve feet away from one another. There was still the added fear that performing outside would leave us susceptible to the elements, and though we had scheduled bad weather make up performances we hadn't rented out the sound equipment through the make-up performance dates. So, even though we were exceptionally close to performing, every moment was layered with doubt and the thought that every performance could be our last. 
The addition of the band to the space, while very important to understanding the scope of our story, was definitely an added frustration. We didn't hire an orchestra to perform with us, most of our band was made of young undergrad students led by our Music Director, Antonio Duran, a first-year graduate student at the University. To say putting them in and having them learn our entire show in less than a week and a half was a challenge is an understatement. the quickness of the process proved to be daunting to a lot of the younger musicians, mainly Ryan Walker our lead keyboardist, who had trouble keeping up with the pace of this show, not being adapt at the improvisational nature a lot of the songs specifically, in my solo that started "I'll Cover You (Reprise).” Up until our opening night, Ryan had trouble following my lead, even going so far as to saying that we might be better off finding a pianist who was better at improvising. Luckily, during one of our final dress rehearsals R.J. Nestor sat in and worked through "I'll Cover You (Reprise)" and many other songs with Ryan and the band to a point where they felt a lot more comfortable performing the show and following the lead of the actors. For a first-year student who came into this production with little time to prepare and be thrown into playing lead keyboard for the show, Ryan did an exceptional job. He embodied the spirit of the struggling artist and fit perfectly into the company.

The addition of costumes and makeup to the performance allowed us to get a sense of the world we were building in our minds as it became reality on stage with us. I must give my utmost gratitude to our amazing designer, Professor Mary McClung. She did an incredible job populating the world of our production with interesting and historically accurate costumes. The set being as sparse as it was, opened up a lot of room for imagination but populating this cityscape with our costumed ensemble added an important amount of specificity to the work. We were able to solidify our relationships with each other because we had that added element of 
knowing who we were looking at and being able to make judgments based off their characters' personal aesthetics. for example, I was able to see the character of Roger's desire to emulate '70s rockers by just observing his costume his cut-off, sleeveless t-shirt, gaudy tattoos, and his constant use of heavy- handed eyeliner was and important puzzle piece that I was missing when interacting with Eli out of costume. It keyed me into more of why Collins was so frustrated with Roger and his refusal to participate. Roger was stuck in the past, emulating his idols, concerned more about image and legacy than with living in his reality and changing the world Collins was working so hard to make livable for the people he cares about. 


\section{Pre-Show Ritual}

There is ritual to every actor's process, and mine was very reliant on the schedule of the performances. Integrating the exercises of Linklater's Dropping and Chekhov's Imaginary Body, before every show I would walk thirty minutes to the Louie, Valerie, and William Canady Creative Arts Center (CCAC), listening to nothing but the city of Morgantown, West Virginia on the way. I would take this time to think about how Tom Collins would feel in a similar situation, and I would step into his imaginary body, walking with him the entire way to the Creative Arts Center. We had to meet at the CCAC and get ready for the performance at the Hazel Ruby Amphitheater, putting on makeup and changing into costumes, before driving in four separate vans to the performance space. Now, being a graduate student at the university I was insured to drive the vehicles, so I was tasked with taking one of the vans full of actors to the space every night. I was very uncomfortable having to drive six to seven actors, including myself, to the performance space every night because I very rarely drive anywhere myself, let alone chauffer other people. The responsibility I had to not only get to the space in time, but to let myself and other actors, other members of my ensemble that I had gotten to know and trust and love in this short process very nearly took me out of a lot of the prep work I had done before arriving at the creative arts center because I was so focused on my driving. That stress and having to reevaluate where I was character-wise every night became something of a ritual itself.

I have never been able to thrive in low-stress situations. I have always performed my best whenever I was rushing against a clock to finish a deadline or when I have taken on more tasks than I think I can complete, so the rush of this process meshed well with my own process of preparation. I found it helpful to check in with my castmates right before every performance to help allay some of our fears and nervous jitters. If there was a general unease or nervousness 
about how the performance would go, I would do my best to comfort and build up the actors backstage, leaning into the idea that Collins plays a similar role in his community. I find it intriguing how certain actors prepare for their roles. Other actors find comfort in quieting their mind before performing or relaxing their body so they know it will be reliable physically capable of carrying them through the length of the performance. For me, it was most beneficial to build upon my sense of community and delve into the emotional life of Collins before every show. 


\section{Evaluation}

As an artist, I have grown to value the community I build with every performance I am a part of. Realizing that art reflects life not just in performance but in process as well has been a lesson hard learned. My entire life I was told that I wouldn't make anything of myself if I wasn't perfect, if I wasn't the best, but life is never perfect. Life is entropy, the return to chaos. So, if life is not perfect, why does every performance have to be?

Through this process I found that living as our characters and creating bonds with our cast, with our crew, and the creative teams really does create a company of people who are willing to put themselves aside for the betterment of others. Performing Rent at such an inopportune time in our world has shown me that if people work together, share ideas, and give their hearts to each other that there is little we cannot accomplish.

It took us less than a month to devise, rehearse, and perform this musical. It was one of the most stressful and hectic pieces that I have been part of, both professionally and in an educational setting and yet the friendships I made with people I met along the way are as strong as relationships I have had almost my entire life. Forged in fire, we were determined to succeed. The overwhelming positive response from members of our audience, telling us that it was just a "treat to be able to experience live theater again," was a success more thrilling than nailing every note, every night. A success more thrilling than saying every line with perfect intention. Real human connection trumps perfection every time.

What a blessing it was to even rehearse this process in person. The semester leading up to this show was the hardest semester of my life. Succumbing to the whims of the coronavirus in the fall 2020 semester really put what we are able to do into perspective. There is a palpable energy that comes from interacting with our fellow human beings. 
It took me months of sitting silently in a small apartment, alone with my thoughts to realize that the structure I craved was distracting to the actor I wanted to become. There are so many people who idolize this profession, wanting it to be a vehicle for fame and fortune but never realizing what they crave is to just be seen. I have learned that the real job of an actor is just the opposite. We are meant to see others; we are reflecting what we observe onto a sea of minds and hearts wanting to be changed. That hunger of wanting to be seen ourselves is just our collaborative spirit pushing its way through.

I don't think that this sense of wanting community was made in the vacuous space of the rehearsal hall or on the stage, but it is a culmination of experiences I have had in my educational process. My time here at West Virginia University, in the MFA Acting program has not only taught me how to be a better actor or to be a performer or artist, but to be a better person. In finding Tom Collins I was able to find a better way to define myself. When we strip away what we are to other people, our professions, our relationships, our political and social identities, we were able to think of ourselves as our ideas and our collective experiences. That is living truthfully and living truthfully under imaginary circumstances is at core of every actor's process. 


\section{Bibliography}

Adams, Tim. "Interview Tom Waits: 'I Look like Hell but I'm Going to See Where It Gets Me." The Guardian, 22 Oct. 2011.

“Allen Ginsberg.” The Herald, April 10, 1997. https://advance.lexis.com/api/document?collection=news\&id=urn:contentItem:3S4Y -DV50-0018-553V-00000-00\&context=1516831

Armstrong, Linda. "NYTW Celebrates 25th Anniversary of 'Rent' at All-Star Studded Virtual Event." New York Amsterdam News, 18 Mar. 2021, pp. 17-21. EBSCOhost, search.ebscohost.com/login.aspx $?$ direct $=$ true $\& d b=a 9 h \& A N=149456902 \&$ site $=$ ehost -live \&scope=site.

CDC. "A Cluster of Kaposi's Sarcoma and Pneumocystis Carinii Pneumonia among Homosexual Male Residents of Los Angeles and Range Counties, California." Centers for Disease Control and Prevention, Centers for Disease Control and Prevention, www.cdc.gov/mmwr/preview/mmwrhtml/00001114.htm.

Chekhov, Michael, Mel Gordon, Mala Powers. On the Technique of Acting. Harper Perennial, 1991.

Cheng, Kipp. “Jonathan Larson.” Entertainment Weekly, no. 359/360, Dec. 1996, p. 34. EBSCOhost, search.ebscohost.com/login. asp ?direct=true $\& \mathrm{db}=\mathrm{a} 9 \mathrm{~h} \& \mathrm{AN}=9701060654 \&$ site=ehostlive \&scope $=$ site. 
Miller, Cait. "Finding Jonathan Larson's Lost Works in Tapes and BOXES...AND Turning Them into a Show." In The Muse: Performing Arts Blog, 6 Sept. 2018, blogs.loc.gov/music/2018/09/finding-jonathan-larsons-lost-works-in-tapes-and-boxesand-turning-them-into-a-show/.

Green, Jesse. "A Brief History of Gay Theater, in Three Acts". The New York Times, March 4, 2018. advance-lexiscom.wvu.idm.oclc.org/api/document?collection=news\&id=urn:contentItem:5RSVRK41-JBG3-602C-00000-00\&context=1516831. Accessed May 7, 2021.

Ginsberg, Allen. Howl, And Other Poems. San Francisco: City Lights Pocket Bookshop, 1956.

Ginsberg, Allen and Bill Morgan. The Letters of Allen Ginsberg. Da Capo Press, 2008

Haasch. If a Queer Character Dies, is it 'Bury Your Gays?' Minnesota Daily: University of Minnesota. https://advance-lexiscom.wvu.idm.oclc.org/api/document?collection=news\&id=urn:contentItem:5VFNKTD1-JBSN-30FT-00000-00\&context=1516831.

“History of HIV and AIDS Overview." Avert, 10 Oct. 2019, www.avert.org/professionals/history-hiv-aids/overview.

"HIV and African American People." Centers for Disease Control and Prevention, Centers for Disease Control and Prevention, 20 Jan. 2021, www.cdc.gov/hiv/group/racialethnic/africanamericans/. 
Pastorek, Whitney. “One Show Glory.” Entertainment Weekly, no. 981, Mar. 2008, pp. 54-58. EBSCOhost, search.ebscohost.com/login. aspx $?$ direct $=$ true $\& d b=a 9 h \& A N=31254492 \&$ site $=$ ehostlive $\&$ scope $=$ site.

Piepenburg, Erik. Gay Theaters Now Struggle to Evolve. The New York Times, September 22, 2013. https://advance-lexiscom.wvu.idm.oclc.org/api/document?collection=news\&id=urn:contentItem:59DHXWT1-DXY4-X47C-00000-00\&context=1516831.

Istel, J. “Jonathan Larson Talks About His Writing Process and Making Rent." American Theatre (July 1996). https://www.americantheatre.org/1996/07/01/jonathan-larson-talksabout-hiswriting-process-and-rent/

Khoshgam, Cameron. “Rent Journal.” Unpublished. 2021

Larson, Jonathan. Rent. 1996. Musical Theatre International, 2017. Print.

Linklater, Kristin, and Andre Slob. Freeing the Natural Voice: Imagery and Art in the Practice of Voice and Language. Hollywood, Calif: Drama, 2007. Print.

Rapp, Anthony. Without You: A Memoir of Love, Loss, and the Musical Rent. Simon \& Schuster, 2006. Print.

Rich, Frank. "Review/Theater: Perestroika; Following an Angel for a Healing Vision of Heaven on Earth.” The New York Times, November 24, 1993. https://advance-lexiscom.wvu.idm.oclc.org/api/document?collection=news\&id=urn:contentItem:3SC6-VB700024-J17P-00000-00\&context $=1516831$. 
Snyderman, Nancy. "Jonathan Larson and Rent." ABC NEWS. Aug. 12, 1999. https://advancelexis-com.wvu.idm.oclc.org/api/document?collection=news\&id=urn:contentItem:3X591J70-007D-Y2K3-00000-00\&context=1516831.

Stanislavsky, Konstantin. An Actor Prepares. New York: Theatre Arts, 1946. Print.

Tepper, Alsey. “Finding Jonathan Larson's Lost Works in Tapes and Boxes ... and Turning Them into a Show.” Impact News Service. https://advance-lexiscom.wvu.idm.oclc.org/api/document?collection=news\&id=urn:contentItem:5T7J-7YK1JDG9-Y2BB-00000-00\&context=1516831.

The Hollywood Reporter. “Actors Roundtable: Chadwick Boseman, Timothée Chalamet, Mahershala Ali, Viggo Mortensen.” Close Up. (YouTube, 21 Jan. 2019)

"Theater; The Seven-Year Odyssey That Led To 'Rent' (Published 1996)". Nytimes.Com, 1996, https://www.nytimes.com/1996/03/17/theater/theather-the-seven-year-odyssey-that-ledto-rent.html. Accessed 27 Apr 2021.

Tommasini, Anthony. "Some Advice for 'Rent' From a Friend." The New York Times, July 28, 2002 Sunday. advance-lexiscom.wvu.idm.oclc.org/api/document?collection=news\&id=urn:contentItem:46CR-GV4001CN-H2T5-00000-00\&context=1516831. Accessed April 10, 2021.

Waits, Tom. "Come On Up to the House". Spotify. open.spotify.com/track/7zhbOCrOKbncbqKvSwQx9R?si=a67013947e9d4c66

—_. "So Long I'll See Ya". Spotify. open.spotify.com/track/7wRFVEtyo6pfRZxBPJtAsJ?si=828452ca1d21451f 